\title{
The assessment of preterm labor cases in terms of maternal fetal aspects
}

\author{
Emine Arslan' (iD), Fikriye Karanfil Yaman² (iD), Turgay Şener ${ }^{3}$ \\ ${ }^{1}$ Department of Obstetrics and Gynecology, Faculty of Medicine, Hitit University, Çorum, Turkey \\ ${ }^{2}$ Department of Obstetrics and Gynecology, Konya Training and Research Hospital, University of Health Sciences, Konya, Turkey \\ ${ }^{3}$ Gynecologist and Obstetrician, Eskişehir, Turkey
}

\begin{abstract}
Objective: The aim is to identify the reasons of preterm labor, which is the most important reason for perinatal mortality and morbidity, and of morbidity and mortality seen in mothers and babies due to preterm labor, to help the development of strategies to eliminate these reasons, and to provide guidance for the planning of efficient treatment model, if any.

Methods: Of 1095 patients who admitted to the Department of Obstetrics and Gynecology, Faculty of Medicine, Eskişehir Osmangazi University and had labor between January 2008 and January 2010, 213 (19\%) had preterm labor between 20 weeks and 36 weeks and 6 days of gestation. Of these 213 patients, 185 whose records could be accessed and the newborns of these labors were included in the study. The data were obtained from the patient files retrospectively.

Results: In our study, $19 \%$ of all labors were preterm labor. Of preterm labors, the reason for $51.9 \%$ was spontaneous onset of preterm labor, $7 \%$ was premature rupture of membrane, and $38.9 \%$ was maternal-fetal problems. When the weeks of gestation and the complications of newborn period were evaluated, it was seen that the mortality rate and the complications such as intracranial hemorrhage, convulsion, respiratory distress syndrome, intubation, surfactant need and newborn retinopathy increased as the gestational age decreased.

Conclusion: Preterm labor is one of the most significant perinatal mortality and morbidity reasons. The low socioeconomic level and insufficient antenatal care capabilities increase these risks further. In our study, we reached the conclusions supporting the results that the mortality rates and prematurity-associated complications in premature newborns correlate with the birth weight and gestational age during labor, and the decrease in them leads to a decline in the survival rate.
\end{abstract}

Keywords: Preterm labor, spontaneous onset of preterm labor, maternal fetal morbidity, mortality.

\section{Özet: Erken doğum yapan olguların maternal fetal} açıdan değerlendirilmesi

Amaç: En önemli perinatal mortalite ve morbidite nedeni olan erken doğumun ve buna bağlı olarak anne ve bebekte görülen morbidite ve mortalitenin nedenlerini saptamak, bu nedenlerin ortadan kaldırılmasına yönelik stratejilerin geliştirilmesine yardımcı olmak ve eğer varsa etkin tedavi modelinin planlanmasında rehberlik görevi oluşturmaktır.

Yöntem: Ocak 2008 ile Ocak 2010 yılları arasında Eskişehir Osmangazi Üniversitesi Tıp Fakültesi Kadın Hastalıkları ve Doğum Bölümüne başvuran ve doğum yapan toplam 1095 hastadan 213'ü (\%19) 20 hafta ile 36 hafta 6 gün arasında preterm doğum yapmıştı. İki yüz on üç hastadan, hastane kayıtlarına ulaşılabilen 185 hasta ve bu gebelikler sonucu doğmuş olan yenidoğanlar çalışmaya dahil edildi. Veriler hasta dosyalarından retrospektif olarak sağlandi.

Bulgular: Çalışmamızda, tüm doğumların \%19’u preterm doğum idi. Preterm doğumların \%51.9'u preterm eylem, \%7'si erken membran rüptürü, \%38.9'u ise maternal-fetal problemler nedeniyle gerçekleşmişti. Doğum haftası ile yenidoğan dönemine ait komplikasyonlar değerlendirildiğinde, gestasyonel yaş azaldıkça intrakraniyal kanama, konvülziyon, respiratuvar distres sendromu, entübe edilme, surfaktan ihtiyac1, yenidoğan retinopatisi gibi komplikasyonların ve mortalitenin arttığı görüldü.

Sonuç: Preterm doğum en önemli perinatal mortalite ve morbidite nedenlerindendir. Sosyoekonomik düzeyin ve antenatal bakım imkanlarının düşüklüğü bu riskleri daha da artırmaktadır. Çalışmamızda, prematür bebeklerde mortalite hızlarının ve prematüriteye bağlı komplikasyonların doğum ağırlığı ile doğumdaki gestasyonel yaşa bağlı olduğunu ve her ikisindeki düşüşün de sürvide azalmaya neden olduğunu destekleyen sonuçlara ulaştık.

Anahtar sözcükler: Preterm doğum, preterm eylem, maternal fetal morbidite, mortalite.

Correspondence: Emine Arslan, MD. Department of Obstetrics and Gynecology, Faculty of Medicine, Hitit University, Çorum, Turkey. e-mail: ekaranfildr@gmail.com / Received: October 13, 2019; Accepted: December 9, 2019

Please cite this article as: Arslan E, Karanfil Yaman F, Şener T. The assessment of preterm labor cases in terms of maternal fetal aspects. Perinatal Journal 2019;27(3):130-136. doi:10.2399/prn.19.0273002 


\section{Introduction}

Preterm labor is defined as the occurrence of delivery after the viability limit of pregnancy and before 37 weeks or 259 days. $^{[1]}$ The prevalence of preterm labor is $10-11 \%$ in all pregnancies. ${ }^{[2]}$ Today, preterm labor is the most important factor affecting the future of fetus without any anomaly and it is still the most important reasons of perinatal mortality and morbidity. The problems encountered during early periods such as respiratory distress syndrome (RDS), intraventricular hemorrhage (IVH) and necrotizing enterocolitis (NEC) are seen more frequently in the premature newborns compared to the newborns which were born at term. ${ }^{[3]}$ In the late period, the problems such as cerebral palsy, visual impairments and hearing losses are seen more frequently in the premature newborns. ${ }^{[4]}$ Despite the efforts to prevent preterm labor, desired results cannot be always achieved due to the difficulties to understand the underlying pathophysiology, insufficient diagnosis methods and inefficient treatments. The increase in the multiple pregnancy rates and obstetric procedure frequency leads to the increased rates of preterm labor. ${ }^{[5]}$ Severe mortality and morbidity rates associated with the preterm labor complications have been reported mostly in the labors before 34 weeks of gestation. In terms of neonatal mortality rates, $83 \%$ of them were reported in the cases which were born before 37 weeks of gestation. ${ }^{[6,7]}$

Our aim in this study is to identify the diagnosis and treatment of preterm labor and spontaneous onset of preterm labor, which are the most important reasons for perinatal mortality and morbidity, and the reasons of morbidity and mortality seen in mothers and babies, to help the development of strategies to eliminate these reasons, and to provide guidance for the planning of efficient treatment model, if any. In this way, we aim lower morbidity and mortality rates.

\section{Methods}

Of 213 patients who had preterm labor between 20 weeks and 36 weeks and 6 days of gestation between January 2008 and January 2010 at the Department of Obstetrics and Gynecology, Faculty of Medicine, Eskişehir Osmangazi University, 185 whose files could be accessed and the newborns which were born in these deliveries were included in our study. The data were obtained from the patient files retrospectively. All patients whose files could be accessed were included in the study without establishing any exclusion criteria.

Maternal demographic characteristics, maternal medical history, preterm labor reasons and newborn mortality and morbidity associated with preterm labor were evaluated in the study. Before initiating the study, the approval was obtained from the ESOGÜTF Ethics Committee (no. 12, dated 21/5/2010). The data of the participants were accessed from their files retrospectively and their identities were kept confidential.

All data analyses were performed by using SPSS 15.0 (SPSS Inc, Chicago, IL, USA) and SigmaStat 3.5 (Systat Software, Inc., San Jose, CA, USA). Continuous quantitative data were expressed as n, mean and standard deviation while qualitative data were expressed as $\mathrm{n}$ and percentage. The data consisting of independent measurements and representing normal distribution were tested by one-way ANOVA and t test depending on the group number, and Pearson's correlation tests were used to determine the correlation between the groups. The data consisting of independent groups were analyzed by Kruskal-Wallis and Mann-Whitney $U$ tests depending on the group numbers of the data consisting of score variables not representing normal distribution, and Spearman's correlation tests were used to determine the correlation between the groups. Chi-square test was used for the data sets in categorical structure. $p<0.05$ was considered statistically significant.

\section{Results}

The demographic characteristics and obstetric history data of the patients included in the study are shown in Table 1.

Fifty-one $(27 \%)$ of the patients who underwent preterm labor had hypertension. A total of 17 (9.1\%) patients had diabetes mellitus, three $(1.6 \%)$ of which were type 1 , one $(0.5 \%)$ of which was type 2 and $13(7 \%)$ of which were gestational diabetes mellitus, 1 patient $(0.5 \%)$ had cardiac disease, 4 patients $(2.2 \%)$ had respiratory system disease, 1 patient $(0.5 \%)$ had kidney disease, and $9(4.9 \%)$ patients had thyroid disease. No correlation has been found between the preterm labor reasons and maternal heart, lung, kidney and thyroid diseases.

In the admissions of pregnant women, the preterm labor reasons were determined as follows: spontaneous onset of preterm labor, fetal distress, premature rupture 
of membranes (PRM) + spontaneous onset of preterm labor, PRM, hypertensive diseases (HELLP + severe preeclampsia, severe preeclampsia), and the other group (intrauterine death, bleeding placenta previa, cervical insufficiency, fetal anomaly, polyhydramnios, anhydramnios, hydrops and maternal disease) (Fig. 1).

A high level of significant correlation was found between preterm labor reasons and newborn mortality $(\mathrm{p}<0.001)$. In our study, the mortality rate of the infants, whose mortality data were accessed $(45 / 205)$, was $219 / 1000$. Of 45 fetal mortality cases, $12(26.7 \%)$ were in the acute fetal distress group. Of 45 mortality cases, 18 $(40 \%)$ were in intrauterine fetal death group, $10(22 \%)$ in acute fetal distress group on the basis of chronic fetal distress, 3 (7\%) were in chronic fetal distress group, 2 (4\%) in the group developing acute fetal distress and $12(26 \%)$ in the group not developing fetal distress. Thirty-one $(70 \%)$ of the mortalities occurred in labors less than $29+6$ weeks, and 15 (48\%) of them were intrauterine fetal death. The number of mortality in the labors between 30 weeks and 30 weeks and 6 days was $8(17 \%)$ and the number of intrauterine fetal death in this group was 2 $(25 \%)$. In labors at 35 weeks and above, the number of mortality was $6(13 \%)$ while the number of intrauterine fetal death was $1(16 \%)$. When the correlation between
Table 1. Demographic characteristics.

\begin{tabular}{|lccc}
\hline Demographic characteristic & $\mathbf{n}$ & $\%$ \\
\hline Age & $<18$ & 3 & 1.6 \\
& $19-34$ & 156 & 84.3 \\
& $\geq 35$ & 26 & 14.1 \\
\hline Gravida & 1 & 87 & 47 \\
& 2 & 41 & 22.2 \\
& 3 & 26 & 14.1 \\
& 4 & 17 & 9.2 \\
\hline Parity & $\geq 5$ & 14 & 7.5 \\
\hline & 0 & 108 & 58.4 \\
& 1 & 43 & 23.2 \\
& 2 & 19 & 10.3 \\
\hline Abortus & 3 & 8 & 4.3 \\
& $\geq 4$ & 7 & 3.7 \\
\hline Living & 1 & 32 & 17.3 \\
& $2-3$ & 15 & 8.1 \\
& $\geq 4$ & 4 & 2.2 \\
\hline The history of preterm labor in previous pregnancy & 119 & 64.3 \\
& 0 & 44 & 23.8 \\
& 1 & 17 & 9.2 \\
\hline & 2 & 5 & 2.7 \\
\hline Week of gestation & 3 & 45 & 24 \\
& $<29$ weeks and 6 days & 74 & 40 \\
\hline Week of gestation & $30-34$ weeks and 6 days & 66 & 36 \\
\hline during delivery & $\geq 35$ weeks & 45 & 24 \\
& $30-34$ weeks and 6 days & 75 & 40 \\
\hline & $\geq 35$ weeks and 6 days & 65 & 36 \\
\hline
\end{tabular}

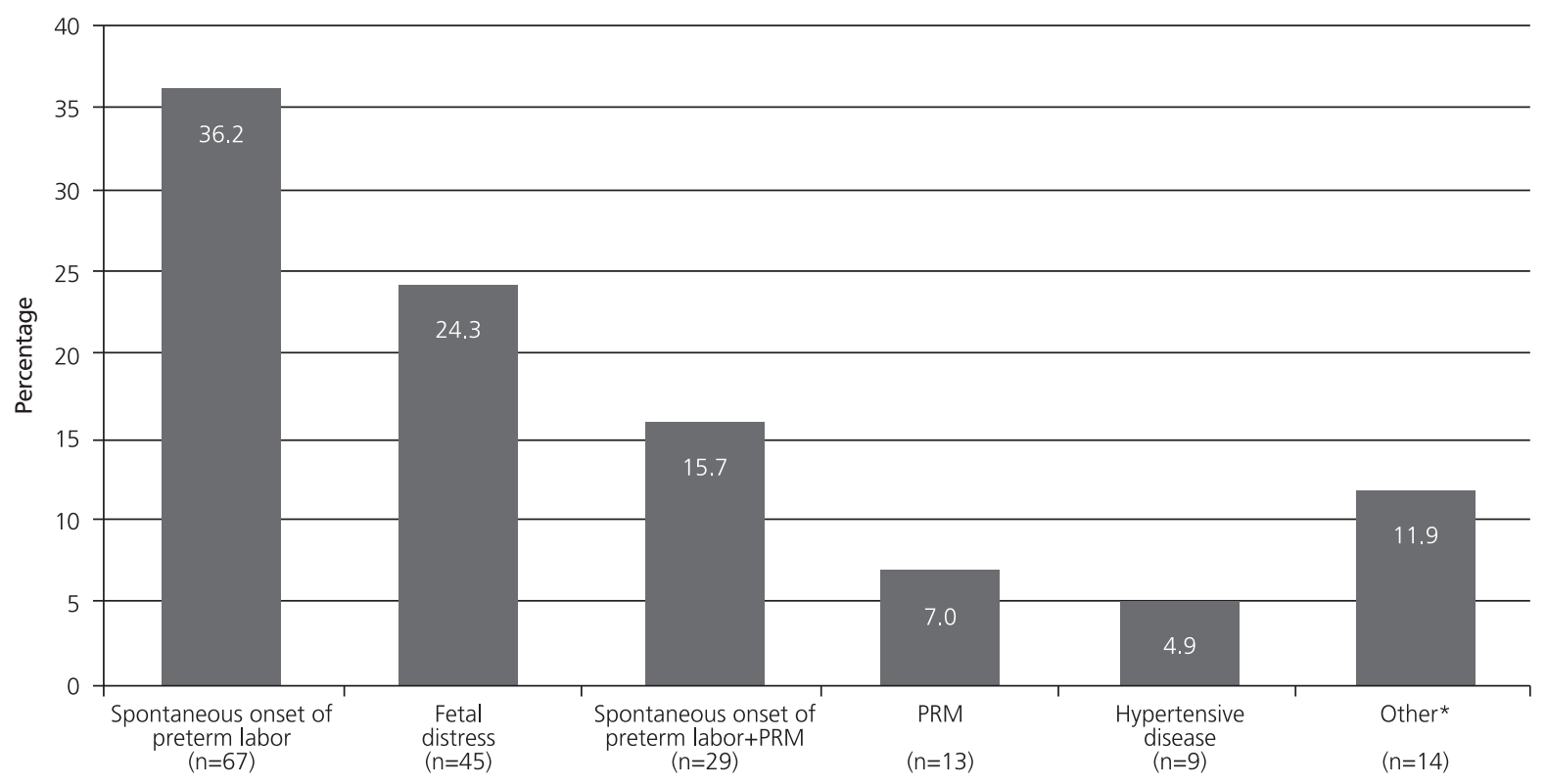

Fig. 1. The reasons of preterm labor at admission for pregnancy. ${ }^{*}$ Other: Intrauterine dead baby, bleeding placenta previa, cervical insufficiency, fetal anomaly, polyhydramnios, anhydramnios, hydrops and maternal disease. 
Table 2. The correlation between the preterm labor reason and the newborn morbidity.

\begin{tabular}{|c|c|c|c|c|c|c|c|c|c|}
\hline & $\begin{array}{l}\text { Spontaneous onset } \\
\text { of preterm } \\
\text { labor }\end{array}$ & PRM & $\begin{array}{c}\text { Placenta } \\
\text { previa }\end{array}$ & $\begin{array}{c}\text { Cervical } \\
\text { insufficiency }\end{array}$ & $\begin{array}{l}\text { Fetal } \\
\text { distress }\end{array}$ & $\begin{array}{c}\text { Severe } \\
\text { preeclampsia }\end{array}$ & $\begin{array}{c}\text { Severe } \\
\text { preeclampsia } \\
\text { + HELLP }\end{array}$ & $\begin{array}{l}\text { Preterm } \\
\text { + PRM }\end{array}$ & p \\
\hline RDS, n (\%) & $10(21.7 \%)^{*}$ & $2(4.3 \%)$ & $1(2.2 \%)$ & $2(4.3 \%)$ & $22(47.8 \%)^{*}$ & $2(4.3 \%)$ & $2(4.3 \%)$ & $5(10.9 \%)$ & $<0.01$ \\
\hline Hyperbilirubinemia, n (\%) & $37(37.8 \%)^{\star}$ & $7(7.1 \%)$ & $4(4.1 \%)$ & $1(1 \%)$ & $25(25.5 \%)^{*}$ & $2(2 \%)$ & $3(3.1 \%)$ & $19(19.4 \%)$ & $<0.05$ \\
\hline Hypoglycemia, n (\%) & $19(26 \%)^{*}$ & $8(11 \%)$ & $2(2.7 \%)$ & $0(0 \%)$ & $32(43.8 \%)^{*}$ & $2(2.7 \%)$ & $1(1.4 \%)$ & $9(12.3 \%)$ & $<0.001$ \\
\hline Intubation need, n (\%) & $12(21.8 \%)^{*}$ & $6(10.9 \%)$ & $0(0 \%)$ & $2(3.6 \%)$ & $24(43.6 \%)^{*}$ & $2(3.6 \%)$ & $2(3.6 \%)$ & $7(12.7 \%)$ & $<0.01$ \\
\hline CPAP need, n (\%) & $21(30 \%)^{*}$ & $7(10 \%)$ & $4(5.7 \%)$ & $0(0 \%)$ & $23(32.9 \%)^{*}$ & $1(1.4 \%)$ & $2(2.9 \%)$ & $12(17.1 \%)$ & $<0.05$ \\
\hline
\end{tabular}

*The group causing the difference.

preterm labor reasons and newborn morbidity was evaluated, it was observed that the rates of RDS, hyperbilirubinemia, hypoglycemia, intubation, and the need for continuous positive airway pressure (CPAP) were higher in cases that underwent preterm labor due to the spontaneous onset of preterm labor and fetal distress (Table 2).

When delivery week and the complications of newborn period were evaluated, a significant correlation was found between delivery week and intracranial hemorrhage, convulsion, RDS, hyperbilirubinemia, hypoglycemia, intubation, CPAP need, mortality, surfactant need and newborn retinopathy (Fig. 2). There was a negative correlation between delivery week and the duration for staying at intensive care unit, the duration for performing intubation and CPAP and the number of applying surfactant.

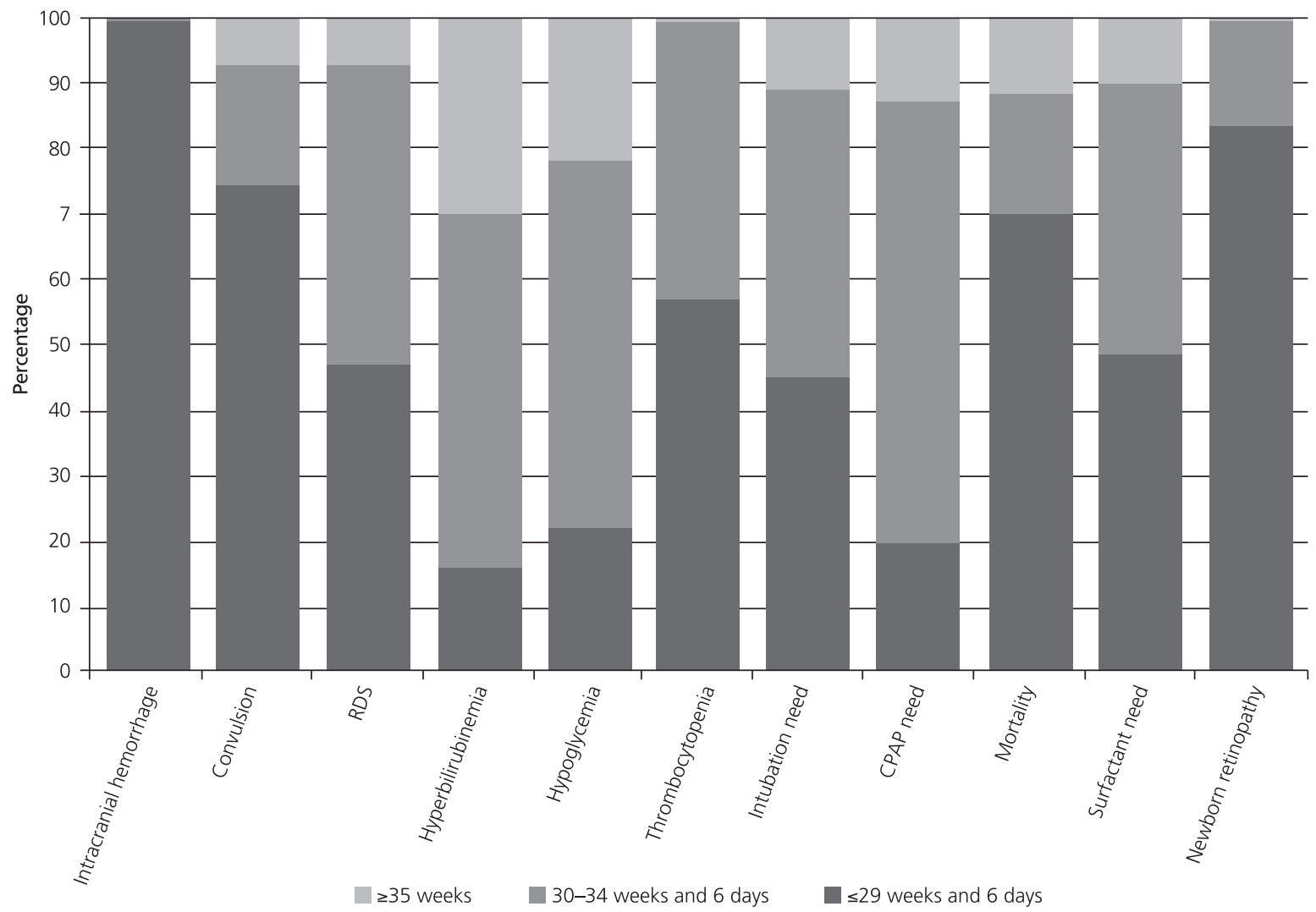

Fig. 2. The correlation between the delivery week and the complications during newborn period. 


\section{Discussion}

Preterm labors, which are the main reason for the newborn mortality and morbidity, constitute $5-18 \%$ of the labors in developed countries. ${ }^{[8]}$ Although there are significant developments in the newborn prognosis with the improvement of care facilities during newborn period, no decline has been obtained in the rates of preterm labor. ${ }^{[9]}$ The rate of preterm labor was $19 \%$ in our study and it is higher than the rates reported in the literature.

$70-80 \%$ of the preterm labors are spontaneous preterm labors. While the reason of $40-50 \%$ of all preterm labors is spontaneous onset of preterm labor, it is PRM in $20-30 \%$ of them. The reason of the remaining $20-30 \%$ of preterm labors is the procedures due to maternal-fetal problems. In our study, the reason of $51.9 \%$ of the preterm labors was spontaneous onset of preterm labor $(36.2 \%$ was spontaneous onset of preterm labor and $15.7 \%$ was spontaneous onset of preterm labor+PRM), and the reason of $7 \%$ of them was PRM. Of the preterm labors, $38.9 \%$ were due to maternal-fetal problems. We believe that finding higher rates of preterm labors and reasons other than spontaneous preterm labors compared to the literature is related with the fact that the tertiary center at which we conducted our study is a referral hospital, the patients have low socioeconomic levels, and antenatal care capabilities are insufficient.

Prematurity-associated complications are the reasons for high mortality and morbidity rates in preterm newborns compared to term newborns. Complication risk increases by the increased immaturity. There are two types of prematurity-associated complications, which are short-term complications during neonatal period (such as respiratory and cardiovascular complications) and long-term complications (the problems associated with neurological development such as cerebral palsy) if newborn lives and is discharged from newborn intensive care unit. ${ }^{[10]}$ Short-term complications also lead to an increase in long-term complications.

In the report published by National Institute of Child Health and Human Development (NICHD) Neonatal Research Network, the complications and their rates seen in the infants with low birth weight which were born between 2003 and 2007 are indicated as follows: ${ }^{[11]}$ RDS (93\%), newborn retinopathy (59\%), patent ductus arteriosus (46\%), bronchopulmonary dysplasia (42\%), late-onset sepsis (36\%), NEC (11\%), grades III and IV IVH (12\%), and periventricular leukomalacia (7-9\%).
Although complication risk decreases as gestational age increases, it was reported in a study in which 6674 newborns born between 30 and 34 weeks were evaluated that the most common complications and their rates were hyperbilirubinemia (59\%), acute RDS (28\%), hypoglycemia $(16 \%)$, and bacterial infection $(15 \%) \cdot{ }^{[12]}$ In our study, the most common complications are hyperbilirubinemia, hypoglycemia and RDS.

Providing the first stabilization of the newborn in the delivery room decreases the short-term complication risk. For example, applying prophylactic surfactant to the newborn in the delivery room helps to decrease RDS and other respiratory complications such as pneumothorax, and interstitial pulmonary emphysema.

Premature newborns face increased short-term complications during newborn period due to anatomic and functional immaturity. The complication risk increases as the delivery week and birth weight decrease ${ }^{[13]}$ A study which evaluated the newborns with low birth weight which were born in 1995-1996 in NICHD Neonatal Research Network centers reported that the newborns with lower weights are more depressed and need more procedures. ${ }^{[14]}$ In our study, the complication data were consistent with those reported in the literature. In our study, fifty-five $(29.7 \%)$ newborns were intubated after birth and 70 (37.8\%) of them needed CPAP. Eight-five (45\%) newborns needed postnatal newborn intensive care unit. Mean hospitalization duration was 12.8 days. The outcomes such as surfactant need, intubation need, intracranial hemorrhage, convulsion and mortality increased as the delivery week decreased.

It was shown in a literature review that survival rate increased as the gestational age and birth weight increased ${ }^{[15-19]}$ The main factor affecting viability is the gestational age.

In a study in which 4446 newborns born at 22-25 weeks between 1998 and 2003 in NICHD Neonatal Research Network were evaluated, the newborns were categorized in death, death or very severe morbidity, death or any morbidity groups, and it was seen that all three conditions decreased dramatically with the increase in the week of gestation. ${ }^{[20]}$

Although the mortality is the highest with a rate of $50 \%$ in the newborns which were born at 25 weeks or below, ${ }^{[15,18]}$ the survival rates of the newborns which were born between 24 and 26 weeks could be increased with the improvements in the newborn care. ${ }^{[15,17]}$ 
The risk factors for death or severe neurodevelopmental disorder for newborns with extremely low birth weight (newborns below $1000 \mathrm{~g}$ ) are bronchopulmonary dysplasia, brain damage, severe retinopathy of the newborn and infection (meningitis, sepsis, and NEC). The mortality risk is 3-5 times higher in late preterm newborns (those born between 34 and 36 weeks) than the term newborns..$^{[21-23]}$

We accessed the mortality data of 205 newborns in our study, and in consistence with the literature, we observed that mortality rates increase noticeably as the gestational age during delivery decreases.

One-year survival also increases as the gestational age increases. ${ }^{[2,25]}$ In addition, increased mortality risks continue for the premature newborns also after 1 year of age compared to the term newborns. In a study conducted in Norway with more than one million individuals who were born between 1967 and 1988 and followed up until 2002, the authors showed that the individuals who were born prematurely (5.2\% of the entire group) had increased death risk during their childhood compared to those born at term. ${ }^{[26]}$ We were unable to obtain information about the postnatal follow-up period of the newborns which were born prematurely and lived, and this was the limitation of our study.

\section{Conclusion}

Consequently, the prematurity-associated complications are the reasons for high mortality and morbidity rates in preterm newborns compared to term newborns. In premature newborns, the mortality rates depend on the birth weight and the gestational age during delivery, and the decline in both of them causes a decrease in the survival rate as well. Therefore, identifying the factors that will cause preterm labor and carrying out active procedures to eliminate these factors would ensure to decrease morbidity and mortality rates.

Conflicts of Interest: No conflicts declared.

\section{References}

1. Morril K. Prerterm eylem ve prematür membran rüptürü. Lambrou NC, Morse AN, Wallach EE, editors. John Hopkins Jinekoloji ve Obstetrik el kitabı. Ankara: Atlas Kitapçılık; 2000. p. $55-60$.

2. Haram K, Mortensen JH, Wollen AL. Preterm delivery: an overview. Acta Obstet Gynecol Scand 2003;82:687-704.
3. Robertson PA, Sniderman SH, Laros RK Jr, Cowan R, Heilbron D, Goldenberg RL, Iams JD, et al. Neonatal morbidity according to gestational age and birth weight from five tertiary care centers in the United States, 1983 through 1986. Am J Obstet Gynecol 1992;166:1629-41.

4. Knoches AL, Doyle LW. Long-term outcome of infants born preterm. Bailieres Clinic Obstet Gynecol 1997;7:633-51.

5. Joseph KS, Kramer MS, Marcoux S, Ohlsson A, Wen SW, Allen A, et al. Determinants of preterm birth rates in Canada from 1981 through 1983 and from 1992 through 1994. N Engl J Med 1998;339:1434-9.

6. Copper RL, Goldenberg RL, Creasy RK, DuBard MB, Davis RO, Entman SS, et al. A multicenter study of preterm birth weight and gestational age-specific mortality. Am J Obstet Gynecol 1993;168:78-84.

7. Kesim M, Karlık İ, Yalçın A, Çalışkan K. Kliniğimizdeki perinatal mortalite oranlarının değerlendirilmesi. Perinatoloji Dergisi 1996;4:88-93.

8. WHO, March of Dimes, Partnership for Maternal, Newborn \& Child Health, Save the Children. Born too soon: the global action report on preterm birth. Geneva: WHO; 2012 May. Available from: www.who.int/maternal_child_adolescent/ documents/born_too_soon/en/

9. Creasy RK, Iams JD. Preterm labor and delivery. In: Creasy RK, Resnik R, editors. Maternal-fetal medicine. 4th ed. Philedelphia, PA: WB Saunders Company; 1999. p. 498-531.

10. Eichenwald, EC, Stark, AR. Management and outcomes of very low birth weight. N Engl J Med 2008;358:1700-11.

11. Stoll BJ, Hansen NI, Bell EF, Shankaran S, Laptook AR, Walsh MC, et al.; Eunice Kennedy Shriver National Institute of Child Health and Human Development Neonatal Research Network. Neonatal outcomes of extremely preterm infants from the NICHD Neonatal Research Network. Pediatrics 2010;126:443-56.

12. Altman M, Vanpée M, Cnattingius S, Norman M. Neonatal morbidity in moderately preterm infants: a Swedish national population-based study. J Pediatr 2011;158:239-44.e1.

13. Fanaroff AA, Stoll BJ, Wright LL, Carlo WA, Ehrenkranz RA, Stark AR, et al.; NICHD Neonatal Research Network. Trends in neonatal morbidity and mortality for very low birthweight infants. Am J Obstet Gynecol 2007;196:147.e1-8.

14. Lemons JA, Bauer CR, Oh W, Korones SB, Papile LA, Stoll BJ, et al. Very low birth weight outcomes of the National Institute of Child health and human development neonatal research network, January 1995 through December 1996. NICHD Neonatal Research Network. Pediatrics 2001;107: E1.

15. Field DJ, Dorling JS, Manktelow BN, Draper ES. Survival of extremely premature babies in a geographically defined population: prospective cohort study of 1994-9 compared with 2000-5. BMJ 2008;336(7655):1221-3.

16. Markestad T, Kaaresen PI, Rønnestad A, Reigstad H, Lossius K, Medbø S, et al.; Norwegian Extreme Prematurity Study 
Group. Early death, morbidity, and need of treatment among extremely premature infants. Pediatrics 2005;115:289-98.

17. Itabashi K, Horiuchi T, Kusuda S, Kabe K, Itani Y, Nakamura $\mathrm{T}$, et al. Mortality rates for extremely low birth weight infants born in Japan in 2005. Pediatrics 2009;123:445-50.

18. Mathews, TJ, MacDorman, MF. Infant mortality statistics from the 2004 period linked birth/infant death data set. Natl Vital Stat Rep 2007;55:1-32.

19. Mathews, TJ, MacDorman, MF. Infant mortality statistics from the 2005 period linked birth/infant death data set. Natl Vital Stat Rep 2008;57:1-32.

20. Tyson JE, Parikh NA, Langer J, Green C, Higgins RD; National Institute of Child Health and Human Development Neonatal Research Network. Intensive car efor extreme premeturity - moving beyond gestational age. $\mathrm{N}$ Engl J Med 2008;358:1672-81.

21. Engle, WA, Tomashek, KM, Wallman, C; Committee on Fetus and Newborn, American Academy of Pediatrics. "Late- preterm" infants: a population at risk. Pediatrics 2007;120: $1390-401$.

22. Raju, TN. Late-preterm births: challenges and opportunities. Pediatrics 2008;121:402-3.

23. McIntire, DD, Leveno, KJ. Neonatal mortality and morbidity rates in late preterm births compared with births at term. Obstet Gynecol 2008;111:35-41.

24. Moser, K, Macfarlane, A, Chow YH, Hilder L, Dattani N. Introducing new data on gestation-specific infant mortality among babies born in 2005 in England and Wales. Health Stat Q 2007;(35):13-27.

25. EXPRESS Group, Fellman V, Hellström-Westas L, Norman M, Westgren M, Källén K, et al. One-year survival of extremely preterm infants after active perinatal care in Sweden. JAMA 2009;301:2225-33.

26. Swamy GK, Ostbye, T, Skjaerven, R. Association of preterm birth with long-term survival, reproduction, and next-generation preterm birth. JAMA 2008;299:1429-36. 